\title{
REINFORCEMENT TECHNIQUES IN OVERCOMING POST-POWER SYNDROME ANXIETY DISORDERS IN THE ELDERLY
}

\author{
M. Athoiful Fanan', Moh. Ilham², Amriana ${ }^{3}$, Ulfa Aulia Handayani4 \\ ${ }^{1}$ An Najah Indonesian Islamic College Mandiri, Sidoarjo, Indonesia, ${ }^{2,3,4}$ Sunan Ampel State Islamic \\ University, Surabaya, Indonesia \\ 1emailatho@gmail.com, 2moh.ilham@uinsby.ac.id, \\ 3amriana@uinsby.ac.id, 4auliaalf306@gmail.com
}

\begin{abstract}
Everyone lives with a variety of presumptions that are not always to their liking, this allows a person to experience tremendous pressure and will foster a prolonged new problem. Post-power syndrome is a phenomenon that occurs in an elderly person who is not ready for old age, motivated by job loss and decreased function of certain organs. Researchers used qualitative research methods through case studies and observations of primary subjects. In this study apply reinforcement work or reinforcement in helping sufferers towards healing, in the form of positive reinforcement on daily good behavior. The results of this study showed that this reinforcement technique has an effect on the healing of post-power syndrome, while involving the participation of the family and the surrounding environment to bring out the meaning in the subject.
\end{abstract}

Keywords: Elderly People, Post-Power Syndrome, Reinforcement

\begin{abstract}
Abstrak: Setiap orang hidup dengan berbagai anggapan yang tidak selalu sesuai dengan keinginannya. Hal ini memungkinkan seseorang mengalami tekanan yang luar biasa dan akan menumbuhkan masalah baru yang berkepanjangan. Post-power syndrome merupakan fenomena yang terjadi pada seorang lanjut usia yang tidak siap menghadapi hari tua, dilatarbelakangi oleh hilangnya pekerjaan dan penurunan fungsi organ tertentu. Peneliti menggunakan metode penelitian kualitatif melalui studi kasus dan observasi terhadap subyek utama. Dalam penelitian ini menerapkan kerja reinforcement atau penguatan dalam membantu penderita menuju kesembuhan, berupa penguatan positif pada perilaku baik sehari-hari. Hasil penelitian ini menunjukkan bahwa teknik penguatan ini berpengaruh terhadap penyembuhan post power syndrome, dengan melibatkan peran serta keluarga dan lingkungan sekitar untuk memunculkan makna pada subjek.
\end{abstract}

Kata kunci: Lansia, Post-Power Syndrome, Reinforcement

\section{A. Introduction}

Work is a common thing that people do, work is also one of the oldest things in the universe. With awareness, a person works to achieve results in accordance with what he expects. According to a number of experts, work involves many aspects, such as the awareness aspect, it is carried out by planning at first, there are certain results to be obtained, and involves other aspects of satisfaction.

Brown's sentence was quoted by Anoraga in an essay, that work is actually an important part of human life, because work is an aspect of life that produces status in society. It seems that this applies to people's lives in Indonesia in particular, people who do not or do not have a job will have a lower status than those who are already working, those who are already working will be judged to have a more meaningful life. That is why many people are looking for work to get rid of feelings of humiliation because of their status in social life.

As we know that work is an activity that a person does, of course, to achieve certain goals, as stated by Kartono that materially, a person can meet the needs of life in the form of salary, 
wealth and various kinds of material facilities, but psychologically work certainly has another purpose, namely as the fulfillment of one's identity, status, and social function in society ${ }^{1}$.

Almost all normal healthy people feel that work can provide a fun and friendly social life. At least this is the main source of happiness, welfare, status, and social security. Therefore, the workplace becomes a center that gives its own meaning in the life of each individual. In addition to ensuring mental health, the workplace office also provides material rewards in the form of wages/salaries, for example, facilities, and outside rewards material in the form of social status, awards and this becomes an extraordinary achievement for the fulfillment of one's dignity².

At a certain point in time, a person has to give himself away from the ties of work, position or power with a pension. Living in retirement has various responses in society, there are those who are happy because they are free from work attachments and the things that have been their responsibilities so far. Not infrequently also feel anxiety and confusion about what to do after retirement. Recent epidemiological studies show evidence that anxiety disorders are among the most common disorders in the general population worldwide ${ }^{3}$.

Anxiety is one of the serious problems in life that goes on. Psychoanalysis holds that anxiety is a tension that motivates a person to do something. There are three kinds of anxiety in life, namely realistic anxiety, neurotic anxiety, and moral anxiety ${ }^{4}$.

According to Indriana, unpleasant changes in a pensioner can cause anxiety and depression. A person will become more sensitive and subjective and result in a lack of reality in facing retirement. This condition then leads to a tendency for people with post-power syndrome.

Living a happy and prosperous old age is certainly everyone's dream, by feeling physically, mentally and socially healthy, feeling needed, feeling loved, and having self-respect and being able to participate in running the wheel of life. Post-power syndrome is mostly experienced by the elderly who have just retired. This term often appears for someone who experiences psychological disorders at the beginning of retirement.

Feelings of stress are generally known to the public as an uncomfortable situation caused by problems beyond one's control, causing a feeling of depression. Stress is considered pressing if it causes psychological reactions such as anxiety, threatened, unhappy, frustrated, unmotivated, depressed, etc. ${ }^{5}$.Feelings of depression, stress, unhappiness and a sense of loss of honor are some of the symptoms experienced by people with post-power syndrome 6 .

Underlying the author of doing this research are several previous studies that also attempt to solve the problem of post-power syndrome, some of which are as follows:

1. Thesis compiled by Anugrah Ragil Putri, a student at the State Islamic University Sunan Ampel Surabaya entitled: "ISLAMIC GUIDANCE AND COUNSELING WITH GESTALT THERAPY IN HANDLING POST-POWER SYNDROME OF A RETIRED SOLDIER IN KEMASAN SIDOARJO".

\footnotetext{
1 Mahsunah Ariyanti \& Yeniar Indriana, "Hardiness and the Tendency of Post-Power Syndrome in Elderly Retired Civil Servants (PNS) Members of the Indonesian Wredatama Association (PWRI) Gajah Mungkur District, Semarang", in the Empathy Journal, vol. 4, no. 1, (January 2015), p. 101.

${ }^{2}$ Abdul Rahmat, Suyanto, "Post-Power Syndrome and Changes in Social Behavior of Retired Teachers", Scientific Journal of Psychology, vol. 3, no. 2, (In 2016), p. 77

3 Soodan S. et al, "Understanding the Pathoshydiology and Management of Age Anxiety Disorders", in International Journal of Pharmacy \& Pharmaceutical Research, vol. 4m no. 3, p. 251-278.

${ }^{4}$ Gerald Corey, Theory and Practice of Counseling \& Psychotherapy, (Bandung: PT Refika Aditama, 2013), p. 17.

${ }^{5}$ Abdul Hamid, et al. "Method of Dhikr to Reduce Stress in Single Parents Women", in Proceedings of the National Seminar on Islamic Psychology, vol. 3, (Surakarta: National Seminar on Islamic Psychology, 2012), p.1.

${ }^{6}$ Agus Santoso, Novia Budi Lestari, "Family Participation in Elderly People with Post-Power Syndrome", in Journal of Media Ners, vol. 2, no. 1, (May 2008), p. 24
} 
2. The thesis written by Lia Amaliatul Islami, a student at the State Islamic Institute of Sultan Maulana Hasanuddin Banten entitled: "SELF HEALING IN OVERCOMING POST-POWER SYNDROME : A Case Study in the Ciputat Indah Complex, Serang City, Banten"

3. Thesis compiled by Ria Oktavia, a student of the College of Health Sciences Bhakti Husada Mulia Madiun entitled: "RELATED POST-POWER SYNDROME WITH ANXIETY LEVEL IN THE ELDERLY RETIREMENT AT KLAGEN VILLAGE, GAMBIRAN, MAOSPATI DISTRICT, MAGETAN REGENCY"

What distinguishes this research from previous research is the technique applied in solving problems related to post-power syndrome. In this case, it is hoped that the implementation of this research can add insight and knowledge that is much newer based on the facts that already exist.

The purpose of this research in general is to find out the causes of the emergence of postpower syndrome disorders experienced by retirees who are the subjects of this study, then specifically this research is a form of solving the post-power syndrome problem experienced by the resource persons who are used as the subject of this research. the subject of this research.

\section{B. Theoretical Review}

\section{Elderly People}

Aging is a series of natural conditions experienced by a person when entering old age. In general, this condition begins with a decrease in strength and physical ability caused by degenerative diseases. The Law of the Republic of Indonesia Number 13 of 1998 states that someone who has reached the age of 60 years and over is called the elderly group (elderly) ${ }^{7}$.Maryam clarifies the elderly into five, including:

a. Pre-elderly, age 45-59 years.

b. Elderly, aged 60 years and over.

c. Elderly high risk, age 60-70 years with health problems.

d. Potential elderly, elderly who are still able to move.

e. Old age is not potential, elderly whose life depends on the help of others ${ }^{8}$.

Based on the classification of the elderly according to Maryam, we know that at certain ages elderly people are allowed to resign/ retire or end attachments work with many parties, because it is undeniable that there are many forms of aging that affect a person's backwardness in doing something. The elderly will experience a decrease in the function and structure of the body's organs and are vulnerable to health due to the aging process. The aging process that occurs naturally certainly brings consequences such as the emergence of physical, mental, and social problems ${ }^{9}$.

Towards entering old age, most of the elderly will experience depression, it is possible that it is closely related to the aging process that occurs in them. Being old is indeed one of the difficult things in the development of human life, a person will experience changes in life, starting with physical decline, psychological progress, and psychosocial.

\footnotetext{
${ }^{7}$ Bambang Suhardi, Brian Pujo Utama \& Taufiq Rochman, "Bathroom Design for the Elderly (Case Study of Panti Wreda Dharma Bakti), at the 2014 IDEC National Seminar, (Surakarta: Lab. Work System Planning and Industrial Ergonomics UNS, 2014)

8 Restyandito \& Erick Kurniawan, "Utilization of Technology by Elderly People in Yogyakarta", in the Proceedings of the XII National Seminar "Industrial and Information Technology Engineering 2017 National College of Yogyakarta, (Yogyakarta: National Seminar XII, 2017), p. 50.

${ }_{9}$ Andi Rahadian, et al. "Designing Wudhu Places for Elderly People", in the Proceedings of the 2013 National Conference On Applied Ergonomics (Yogyakarta: Ergonomics Lab UGM, 2013).
} 


\section{a. Physical decline}

Physical decline is caused by changes in the body's cells, including a decrease in body resistance, the function of the five senses, and memory. Usually accompanied by psychological setbacks.

\section{b. Psychological decline}

Psychological setbacks are often preceded by physical setbacks, usually manifested by a person becoming forgetful, irritable, fussy, and so on.

\section{c. Psychosocial decline}

This setback is caused by the loss of sources of income, social status, and the loss of loved ones, such as life partners, friends or relatives. ${ }^{10}$.

When a person enters the phase of late adult life or old age, a person will experience a number of problems which usually begin with symptoms of insecurity and the presence of excessive anxiety. Among the symptoms that appear in the elderly are:
a. Fear of facing retirement.
b. Feeling useless.
c. Feeling the loss of respect for family and society.
d. Feeling that his life in this world is not long.
e. Feeling weak and helpless.
f. Fear of getting sick.
g. Fear of being left behind or leaving loved ones, such as husband, wife, and children.
h. Fear of death.

Old age, twilight, or old age is the closing period in the span of life, moving away from the previous period which was more pleasant and full of benefits. Therefore, after all, it is best for a person to try to adapt, and believe the results are the same as the foundations instilled in the early stages of life. ${ }^{11}$.

\section{Post-Power Syndrome}

Increased connectivity, interaction, machines, boundaries between humans and other resources in the era of the industrial revolution 4.0 are evidence of the times, people of all ages use social media as a means of getting information, friends, and sharing various important information as a provision for life. Some people may still be unfamiliar with the term post-power syndrome. Post-power syndrome is a picture of a person's emotional changes due to difficulty accepting changes that occur at a certain time, for example someone was once known to be beautiful, smart, and successful at work, but at one time an elderly person will feel that someone is more competent in doing the job, thus making his self-esteem plummeted. And the point is that the drop in self-esteem is due to prestige and shame because it is no longer as successful as it used to be.

Post-power syndrome is a popular syndrome, this syndrome is a psychological reaction in the form of a set of symptoms of illness, injury, and damage to physical and spiritual functions that are aggressive, usually caused by no longer having position and power ${ }^{12}$. For sufferers,

\footnotetext{
${ }^{10}$ Nanik Afida, Sri Wahyuningsih, and Monique Elixabeth Sukamto, "The Relationship Between Fulfillment of Affiliation Needs and Depression Levels in Elderly Women in Nursing Homes" in Anima, Indonesian Psychology Journal, vol. 15, no. 2, p. 184.

11 Yudrik Jahja, Developmental Psychology, (Jakarta: Kencana, 2011), p. 253-254.

12 Khodijah, " Post-Power Syndrome of Retired Civil Servants in Surabaya City", in BioKultur Journal , vol. 7, no. 1, (June 2018), p. 19.
} 
work is a basic need and an important part of life, providing pleasure and satisfaction for a person ${ }^{13}$.

People with post-power syndrome are often in the shadows of their past greatness, in the form of shadows of career, position, intelligence, leadership and so on, things like this seem to make it difficult for them to see the reality that is happening today ${ }^{14}$.

Post-power syndrome is a symptom that shows that the sufferer lives in the shadow of his past greatness, career, power, antiquity, good looks, intelligence, and other great things for him. This is caused by a lack of mental preparation, lack of social development, too standard on the only source of association, a consumptive lifestyle, and a sense of being too active at the end of the term of office/position. ${ }^{15}$.

Post-power syndrome is in the form of symptoms of illness, injury, and progressive deterioration of physical and spiritual functions caused by retirement or loss of power usually. Someone who has this disorder usually thinks that work is a basic need, very important in life and provides its own support system for the perpetrator ${ }^{16}$.

Elderly people who retire from their jobs almost always experience post-power syndrome, these people certainly experience shock and consider their cessation from a job as a loss and disgrace that causes shame, inferiority, useless, forgotten, excluded and like losing home. This mental-down state greatly determines the reactive-mechanism to respond to old age and retirement. If this happens more and more late, it can cause the dementia process to take place more quickly, damage organic functions, and result in various other mental disorders that may accelerate his death.

Ellia defines post-power syndrome is a collection of symptoms, power means power which can then be translated that post-power syndrome is a symptom that appears after power. Generally, this symptom occurs in people who initially have power or positions in society, after losing the position, the psychological symptoms of unstable emotions and so on will surface ${ }^{17}$.

Post-power syndrome is usually preceded by blind anxiety in most elderly people who have just retired from work, Sigmund Freud stated that anxiety is a tense situation that forces one to act, there are three types of anxiety, namely reality anxiety, the golden age of neurotic, and moral anxiety.

a. Reality anxiety, is a fear of danger that comes from outside, and the degree of anxiety of this kind corresponds to the level of real anxiety.

b. Neurotic anxiety is a fear that instincts will get out of line and result in someone doing something that causes punishment.

c. Anxiety moral, is the fear of his own conscience, always feel like someone's contrary to the moral code ${ }^{18}$.

The cause of the outbreak of post-power syndrome usually begins with a person's condition starting to be vulnerable due to age, resulting in feelings of anxiety due to unemployment, loss of position, and so on. Kartono mentioned several causes of post-power syndrome, namely:

a. A person feels left out of the official orbit that he really wants to be constantly in.

b. A person feels excessive disappointment, sadness, and prolonged misery as if his world is a dead-end alley that is difficult to penetrate again.

\footnotetext{
13 Yustinus Semiun, Mental Health 2, (Yogyakarta: Kansinus, 2006), p. 501.

14 Thursan Hakim, Overcoming Distrust, (Bandung: PT Remaja Rosdakarya, 2011), p. 107-109.

15 Rasmidi, The Right Way to Respond to Retirement, (Depok: Indie Publishing, 2012), p. 13.

16 Yustinus Semiun, Mental Health 2, (Yogyakarta: Kansisius, 2006), p. 502.

17 Abdul Rahmat, Suyanto, "Post-Power Syndrome and Changes in Social Behavior of Retired Teachers", in Scientific Journal of Psychology, vol. 3, no. 1, 2016, p. 80.

${ }_{18}$ Gerald Corey, Theory and Practice of Counseling and Psychotherapy, (California: Brooks/Cole Publishing Company), p. 95.
} 
c. Very strong negative emotions, starting from intense anxiety that continues and becomes somatic that affects the circulatory system, heart, and other nervous systems that are serious and at risk of death.

Before becoming a continuous disease, this one syndrome certainly has certain symptoms. In the form of changes in physical and psychological conditions that cannot be controlled by a person alone, it is even difficult to alleviate them with medical or psychiatric assistance. Feelings of discomfort or fear of the surroundings are certainly very disturbing, especially if someone does not understand why there are emotions like this that seem to threaten him.19. Some of the symptoms at the beginning of the occurrence of postpower syndrome, including:

a. Physical symptoms, usually characterized by physical appearance of the patient who looks older, weaker body wash, white hair, moody, increased aging lines, susceptible to disease, decreased stamina, energy, and even the ability to analyze things.

b. Emotional symptoms, this is certainly marked by emotional changes, irritability, often withdraws from social interactions, is quick to anger, does not like to listen to and be denied, and feels no longer worthy.

c. Behavioral symptoms, is characterized by the appearance of unusual behavior, be quiet, shy, often discussing his prowess future ago, insult and criticizing at will, not wanting to be defeated, even to the point of showing anger wherever the place is ${ }^{20}$.

Physical and psychological conditions like this are certainly not easily controlled by individuals themselves, even medical and psychiatry are also difficult to alleviate with certain treatments, things like this are becoming increasingly serious because they can result in shortening the life of the sufferer. There are many factors that influence a person in experiencing post-power syndrome disorders, including:

a. Person's satisfaction in working or doing a job.

When someone has or will enter retirement, automatically satisfaction in a person to work becomes one of the factors for the occurrence of the disorder.

b. Age

Age is a determinant of a person experiencing posr-power syndrome disorder, when a person's age gets older, the pattern of thinking and behavior of a person will certainly decrease.

c. Health

Health is also a definite scourge that affects post-power syndrome, because the older a person gets, the more visible the symptoms of declining health will be.

d. Social status

Before entering retirement, someone must have been in the most comfortable position in terms of status that is recognized by the community, this will make sufferers experience acute depression because they will become ordinary people again after retirement.

Actually, the general criteria for the emergence of post-power syndrome is not the situation or condition of retirement or unemployment, but is related to how a person feels that the new situation is faced with a feeling of relief, satisfaction, and happiness because he has tried to be bound as much as possible until he is free as he was when he was born. this. Unlike many of us today, after retirement, someone with negative emotional power rebels in his own mind, commits violent aggression, explodes explosively, finds it difficult to accept new situations, is disappointed, crushed and various other forms of dissatisfaction. The prevention methods that can be done so that post-power syndrome is not symptomatic in elderly retirees, namely:

a. Make careful planning from an early age so that you can prepare for retirement with confidence without any mental or physical anxiety.

\footnotetext{
${ }^{19}$ Amir N, Textbook of Psychiatry 2nd Edition, (Jakarta: FKUI, 2013), p. 18.

20 Tessie Setiabudi, Joshua Maruta, Retirement Gaul 7 Effective Steps to Prepare for Layoffs, VRP, or Retirement, (Jakarta: PT Gramedia Pustaka Utama, 2014), p. 24.
} 
b. Increase the deepening of religious teachings and draw closer to Allah S.W.T.

c. Follow positive activities to prevent erratic daydreaming. For example, following routine sports, attending regular recitations, and so on ${ }^{21}$.

Meanwhile, the handling of elderly retirees who experience symptoms of post-power syndrome is to encourage support from people in the closest environment, such as family, relatives, and neighbors around the place of residence. Stabilizing also greatly affects the passing of the post-power syndrome phase. Support and understanding from loved ones can really help post-power syndrome sufferers in healing. If the patient can feel the people around him understand his situation, then the patient will be more able to accept his situation and can think coldly. It is believed that it will restore the creativity and productivity of the sufferer even though it is not as reliable as it used to be. It would be different if the family mocked and sarcastically even made fun of the sufferer in going through this phase.

Elderly people really need family intervention in overcoming the problem of post-power syndrome, thus it is hoped that the elderly can live their old age happily, independently, and avoid all kinds of difficulties that might occur. To reduce the problem, the family must be more knowledgeable about post-power syndrome so that they can provide care and guidance that can reduce the problems experienced by the elderly.

\section{Reinforcement}

The reinforcement theory of motivation was proposed by BF Skinner and his colleagues. Their view states that individual behavior is a function of its consequences (stimulus-response-consequence). This theory is based on a kind of law of influence where behavior with positive consequences tends to be repeated, while behavior with negative consequences tends not to be repeated.

This theory focuses entirely on what happens to an individual when he acts. This theory is a powerful tool for analyzing control mechanisms for individual behavior. However, it does not focus on the causes of individual behavior.

In everyday life, many events of strengthening and eliminating behavior occur naturally, which is called natural consequence. However, in a behavior change program, reinforcement is not allowed to occur naturally, but arranged in such a way as to be consequent to the behavior to be improved or maintained. Reinforcement rules are not always easy to do and sometimes complicated. Often a positive reinforcer is very powerful, but often not effective at all. What is reinforcement to one person in a given environment may mean absolutely nothing to another. The complexity in providing the reinforcement actually occurs because the modifier is less careful in observing. According to Sobry Sutikno, there are three principles of effective use of reinforcement, namely:

a. Warmth and enthusiasm.

b. Significance.

c. Avoid using negative responses 22 .

Mulyasa said that there are three objectives of providing reinforcement, namely:

a. Increase client's attention to learning.

b. Stimulate and increase motivation.

c. Improving learning activities and fostering productive behavior [23] .

Meanwhile, according to JJ. Hasibuan and Moedjiono have six purposes for providing reinforcement as follows:

a. Increasing client's attention to learning.

b. Facilitating the learning process.

c. Controlling and changing attitudes that interfere with productive learning behavior.

\footnotetext{
${ }^{21}$ Thursan Hakim, Overcoming Distrust, (Jakarta: Puspa Swaram, 2002), p. 107-111.

22 Fitriani, et al. "The Application of Reinforcement Techniques to Improve Physics Learning Outcomes for Class VIII Students. A SMP Bajeng Gowa Regency", in the journal JPF vol. 2, no. 3, p. 196.
} 
d. Developing and organizing yourself.

e. Leading to good thinking patterns and based on their own initiative[24] .

There are generally two types of reinforcement, positive and negative. Positive reinforcement refers to an increase in the frequency of future behavior due to the addition of a stimulus. For example, a cake is given to the child (addition of stimulus) every time he sits correctly, and the frequency of the child sitting correctly will increase. On the other hand, negative reinforcement refers to an increase in the frequency of future behavior due to the removal of the stimulus. For example, an unpleasant song will be turned off (stimulus) every time the child wakes up in the morning, and the child's early riser behavior increases.

\section{a. Positive Reinforcement}

According to Muh Uzer Usman, in order to provide effective reinforcement, the following tips need to be followed:

1) Reinforcement to a certain person that is clear.

2) Given immediately and immediately after the expected behavior appears.

3) Strengthening through group activities.

4) Applying various reinforcement methods ${ }^{[25]}$.

Then Soetirlah Soekaji mentions the forms of reinforcement that can be used effectively, among others:

1) Food.

2) Objects, according to the preferences or needs of the subject and the location of the handling.

3) Activities/events, namely activities to adjust the subject's interest so that it does not create pressure and plays a good role as a reinforcement.

4) Social action, namely actions that are presented by others socially in verbal and non-verbal language.

\section{b. Negative Reinforcement}

In negative reinforcement, the increase or possibility of repeating the expected behavior is caused by the reduction or elimination of an unpleasant stimulus as a consequence of the behavior. So, behavior gets negative reinforcement, if the behavior is increased or maintained because it is related to or removed from a stimulus.

This negative reinforcement can take many forms. Anything that is potentially unpleasant can become negative reinforcement. However, it should be noted that everyone has a different view of whether an object or treatment that is used as reinforcement is pleasant or not. Silence, ridicule, ignored, and so on can be negative reinforcement that is social in nature.

In the application of behavior change, the use of negative reinforcement should not be too frequent and should be combined with positive reinforcement instead. Among the limitations of negative reinforcement are:

1) The presentation of negative reinforcement is often unpleasant to the changer/practitioner.

2) Repeated presentation of aversive stimuli makes the client more immune.

3) Negative reinforcement effects affect behavior that is not the real target.

Not unlike the use of positive reinforcement, the use of negative reinforcement also requires observation and considering various factors, such as quantity and quality, type, schedule, and so on. It is known that there are two types of negative reinforcement as follows:

1) Escape Conditioning, namely conditioning that occurs because something negative stops.

2) Avoidance Conditioning, namely conditioning that is done by avoiding something negative, happens because behavior is preventing something negative.

\section{Methods}

This research uses a qualitative approach with the type of case study research. A case study is a comprehensive description and explanation of various aspects of an individual, a 
group, an organization, a program, or a social situation ${ }^{[26]}$. In this study, there are 2 variables used, namely reinforcement for the independent variable, and the dependent variable is postpower syndrome disorders in the elderly. The operational definition of this research is: (1) Elderly is a term for someone who has reached the final stage of development in the human life cycle. It is written in the Law of the Republic of Indonesia Number 13 of 1998 that someone who has reached the age of 60 years and over is called the elderly group (elderly). (2) PostPower Syndrome, is a mental condition that is generally experienced by people who have lost power or position, and are followed by a decrease in self-esteem. (3) Reinforcement, is a positive response from practitioners to clients who have done a good deed in an interaction to be able to make the act reappear.

The subject of this research is an old man who is about 70 years old, a retired TNI-AD who has post-power syndrome disorder. The type of data used in this study is non-statistical data, where data will be obtained in the form of descriptions and verbal and not in the form of numbers. The type of data obtained is primary because it comes from the first source in the field through observation methods as well as interviews and literature studies that become references in research related to reinforcement in patients with post-power syndrome disorders. Interviews will be conducted to collect data on (1) overcoming post-power syndrome disorders, (2) application of reinforcement in overcoming disorders post power syndrome. While the observations in this activity are used to review the behavior of the research subjects.

\section{Results and Discussion}

The research was carried out on April 19, 2021. The description of the subject of this research is as follows, Mr. M, an old man around 70 years old, born in Malang City, Javanese ethnicity, adheres to Islam, a former TNI-AD Corporal rank, has 3 sons, is spending a lot of time in the yard with his wife, just fell from a guava tree in front of his house in Subdistrict Sampung, Ponorogo Regency.

Mr. M admitted that he had suffered from post-power syndrome since 15 years ago, namely in 2005, this disorder started when he retired from his official duties in serving the country. The chronology begins when he retired, his three sons were studying in the TNI, 2 of his sons were in the TNI-AL, and 1 was in the TNI-AD. In one's life, it certainly requires a lot of money to stay alive and turn the wheel, he does not have a side job and only relies on his retirement salary, for food, daily necessities, and his son's education costs.

Since then, Mr. M felt useless, after the end of his working period he only spent his time at home and did not earn any money in life. In his home environment, he is a nomad who has no relatives here, and in other places, of course, each of them has been busy with their respective activities, with increasingly old age, of course, making clients unable to connect or share stories with them. No one puts any pressure on the client in fact, but on his responsibility as the head of the family, he feels a great pressure that is difficult to define himself. Many thoughts make him overthinking, such as children who are still alive and better than himself, a life that still has to keep turning its wheels, as well as all kinds of other problems that arise over time. His responsibility towards his family becomes tremendous anxiety for the client, it is difficult for him to accept the fact that he has to move on from the work that has adorned his days for decades. However, as the household atmosphere becomes lighter, the client begins to feel that he must accept the situation and learn to let it go.

Post-power syndrome disorders experienced by clients include the emergence of a sense of worthlessness for the people around them, despair because they feel that their life is dark, the client losing his social status in the community, feeling like a nobody in his environment, feeling sad and confused because no longer involved in making certain decisions, the client becomes often gouty, often has sudden dizziness and bloating that does not heal quickly. Clients crave the busyness that brings a big name for him back again, owned again, and owned forever until the end of his life. In addition, this client had fallen from a guava tree and suffered a fractured femur, 
and received stitches along his thigh with about 12 platinum implants in his thigh, making him unable to walk, and increasingly thinking about various things for the rest of his life. Things like this are very stressful on the client's psyche and result in mental illnesses in the client. The client often daydreams, when he is really dizzy, anxious, and uncomfortable, the client does not hesitate to get angry and screams extraordinary to do whatever he wants to do, after that the client cries sobbing and is silent for a long time. What happened to this client made him feel embarrassed and awkward to those around him in the end. He had faced this for a long time until finally, he decided to ask for the professional help from a counselor to help his recovery.

Reinforcement or strengthening in patients with the post-power syndrome can be done using the power of a rational mind aimed at healing the body both physically and spiritually because in essence, humans have the ability to overcome their own problems. Meditation, doing self-reflection in the sense of the mind so that Allah SWT takes over everything for us.

Mr. M overcomes his post-power syndrome with support/reinforcement from the environment and the people closest to him, especially his extended family. Mr. M finally realizes that he cannot live in the shadow of his past glory. Positive transition Mr. M of post-power syndrome in self-healing or reinforcement include:

a. Awareness arises, namely, the client realizes that being meaningful does not only have to be with a big name and being recognized by his presence, it is enough to carry out his duties and obligations well, remain a good society by continuing to do positive things will make himself much more meaningful. In this healing, the family plays a very important role in calming the client, of course accepting the client with full acceptance, and not making the client feel no longer owned.

b. Motivated to plan new things, after realizing his presence in the environment, the client is important in making plans to live his retirement happily. In this section Mr. M took advantage of his relationships with his former workmates in Sumatra, Mr. M will buy oil palm land there and start organizing his life more quickly and with direction. At that time what was decided sounded awkward and difficult because they still had to borrow bank money for the payment, but now it has seeded unmatched happiness and can be a great investment.

Reinforcement applied by the therapist in the process of self-recovery of a client using the client's own instincts and the moral support of the people around, self-healing procedures like this certainly aim to reduce stress, fear, anxiety, insecurity, and various other mental-emotional problems. Reinforcement can help speed up healing of psychological problems experienced by clients, namely with the support of people around the subject, they will feel more meaningful, positive reinforcements on the improvement efforts made by the subject will run better and experience significant progress from time to time.

Based on the results of the meeting with $\mathrm{Mr}$. M, he overcomes post-power syndrome at first without consulting a psychiatrist or counselor, considering that it is very rare to find professionals in his place of residence. However, after getting various suggestions and input from trusted people, finally the child helped the subject to get a counselor. Some of the things Mr. M before and after meeting the counselor are as follows:

a. In sports, every morning the client does small fitness movements to give his body a refreshing effect, improve brain work, improve memory and emotional control for him so that post-power syndrome disorders are forgotten.

b. Participated in religious activities in the community, before finally falling from a tree and carrying out a series of operations that made him unable to walk Mr. M is a community member who regularly attends congregational meetings at the mosque and participates in regular studies at the mosque. Until he fell, eventually he became more and more listening to tausiyah from the YouTube channel.

c. Get closer to Allah SWT, Mr. M is now a much better servant of God and cares for others, performs worship on time and likes to give to the needy as a form of worship to Allah SWT. Because you can't go to the mosque and worship there, Mr. M perpetuates the reading of dhikr as a form of calming therapy for him, which he reads include the following: (1) 
Tasbih reading (Subhan Allah); (2) Tahmid reading (Alhamdulillah); (3) Reciting tahlil (Laa Ilaaha Illa Allah); (4) Takbir reading (Allahu Akbar).

d. Farming, with the help of crutches or stilts Mr. M always cleans and tidies up his yard, not infrequently his wife is asked to buy seeds and fertilizer for farming. The result is usually enjoyed alone as a daily meal and he is also willing to invite his neighbors to enjoy it. That sense of usefulness and belonging returned to Mr. M.

In addition, the family becomes the main support-system for healing post-Powers syndrome disorders in an elderly person. The family is a source of strength and happiness for an elderly person who can also minimize the anxiety and fear experienced by people with postpower syndrome disorders. It would be better if the family also fully understands related to post-power syndrome disorders, gains support and motivation because then the sufferer will feel much safer in the protection of the family. [27]

In this case study, positive reinforcement is also given by neighbors in the subject's neighborhood, by clearly replying to the subject's greeting, accompanying him in joking in the morning and evening, and occasionally enjoying the results of the subject's cultivation. This is done to foster a sense of meaning in the subject, namely a sense of belonging to everyone and not changing from before and after retirement.

\section{E. Conclusion}

The cause of post-power syndrome disorder is the unpreparedness of an elderly person in facing retirement or twilight after losing his permanent job, usually characterized by anxiety about the future that surrounds him, there are feelings of wanting to return to the previous world, not realizing that the potential in him is naturally occurring. gradually began to decline, as well as various kinds of insecurity in an elderly person. In the case of Mr. This M is preceded by a feeling of worthlessness that arises and becomes a powerful emotion that affects a person's life.

The effectiveness of the reinforcement applied by the counselor shows a positive response, by involving the entire extended family and community environment in providing a sense of meaning that the client feels that he is starting to accept his reality (self-acceptance), the client will feel that his days are getting better. Every daydream of the past come, the client will directly do things that can inhibit or eliminate the incident.

The healing of clients with post-power syndrome disorders is certainly closely related to the contribution of the family in helping the healing process, therefore it is important for family members or closest relatives of sufferers to understand and understand details related to problems related to the disorder.

\section{References}

Afida, Nanik, et al. "The Relationship Between Fulfillment of Affiliation Needs and Depression Levels in Elderly Women in Nursing Homes". In Anima, Indonesian Psychology Journal. Vol. 15. No. 2.

Ariyanti, Mahsunah. Indriana, Yeniar. "Hardiness and Tendency of Post-Power Syndrome in Elderly Retired Civil Servants (PNS) Members of the Republic of Indonesia Wredatama Association (PWRI) Gajah Mungkur District, Semarang". Empathy Journal Vol.4. No. 1 January (2015)

Corey, Gerald. Theory and Practice of Counseling \& Psychotherapy. 2013. Bandung: PT Refika Aditama.

Fitriani, et al. "The Application of Reinforcement Techniques to Improve Physics Learning Outcomes for Class VIII Students. A SMP Bajeng Gowa Regency". JPF Journal Vol. 2. No. 3. 
G. Corey. Theory and Practice of Counseling and Psychotherapy. California: Brooks/Cole Publishing Company Media Ners Vol. 2. No.1, May (2018).

Grace, Abdul. Suyanto. "Post-Power Syndrome and Changes in Social Behavior of Retired Teachers" . Scientific Journal of Psychology Vol. 3. No. 2 (2016)

Hamid, Abdul, et al. "Dhikr Method To Reduce Stress In Single Parent Women ". Proceedings of the National Seminar on Islamic Psychology. Vol. 2. (2012). Surakarta: National Seminar on Islamic Psychology.

Hasibuan, JJ. Moedjono. Teaching and Learning Process. Bandung: PT Rosdakarya, 2008.

Jahja, Yudrik. Developmental Psychology. Jakarta: Kencana, 2011.

Judge, Thursan. Overcoming Distrust. Bandung: PT Pemuda Rosdakarya, 2011.

Khodijah. "Post-Power Syndrome for the Elderly of Retired Civil Servants in the City of Surabaya". In the Journal of Bioculture . Vol. 7. No. 1. (2018)

Mulyana, Deddy. Qualitative Research Methods: A New Paradigm of Communication and Other Social Sciences. Bandung: Youth Rosdakarya, 2002.

Mulyasa. Becoming a Professional Teacher (Creating Creative and Fun Learning). Bandung: PT Pemuda Rosdakarya, 2008.

N. Amir. 2nd Textbook of Psychiatry. Jakarta: FKUI, 2013.

Usman, Uzer. Becoming a Professional Teacher. Bandung: PT Pemuda Rosdakarya, 2001.

Rasmidi. The Right Way to Respond to Retirement. Depok: Indie Publishing, 2012.

Restyandito. Kurniawan, Erick. "Utilization of Technology by Elderly People in Yogyakarta". Proceedings of the XII National Seminar "Industrial and Information Technology Engineering 2017 Yogyakarta National College of Technology. 2017. Yogyakarta: National Seminar XII.

Rahadian, Andi, et al. "Planning Wudhu Places for the Elderly". Proceedings of the National Conference On Applied Ergonomics 2013. Yogyakarta: Lab. Ergonomics.

Santoso, Agus. Lestari, Novia Budi. " Family Participation in the Elderly with Post-Power Syndrome". Journal of Media Ners. Vol. 2. No. 1. May (2008).

Semiun, Justin. Mental Health 2. Yogyakarta: Kansinus. 2006.

Soodan S. et al. "Understanding the Pathophysiology and Management of three Anxiety Disorders". International Journal of Pharmacy \& Pharmaceutical Research. Vol. 4. no. 3 .

Suhardi, Bambang. Utomo, Brian Pujo. Rochman, Taufiq. "Bathroom Design for the Elderly (Case Study of Panti Wreda Dharma Bakti)". IDEC 2014 National Seminar. Surakarta: Lab. Work System Design \& Industrial Ergonomics UNS. 